\title{
A BUDAPESTI BARNAMEZŐS TERÜLETEK ÚJRAHASZNOSÍTÁSA
}

\author{
LEPEL ADRIENN*
}

A cikk a budapesti barnamezős területek ,újrafejlesztési” folyamataival foglalkozik. Bemutatja az ipar fejlődését és a várható irányzatokat. Röviden összefoglalja a főváros településszerkezetének, ipari területeinek változásait a XIX. századtól napjainkig. Leírja a barnamezős területek kialakulását, a kezdeti újrahasznosítási folyamatokat.

Példák vizsgálatával elemzi Budapest két barnamezős területének: a nagytétényi Metallochemia telkének és a Váci út térségének megújulását. A cikk bemutatja az ipartelepek történetét, az újrafejlesztés folyamatát, a területen található ipari épületek sorsát, valamint gazdaságossági kérdéseket. A vizsgálati szempontok között szerepelt többek között a településszerkezeti tervek hatása, az önkormányzat szerepe, valamint az új funkció igényei.

Elsőként a nagytétényi területet vizsgáltam. Az egykori Metallochemia fejlesztése állami kezdeményezéssel, a belvárostól távol megy végbe. A területen a talajszennyezés meghatározta a fejlesztés módját. Bemutatom, hogyan jelent megoldást a problémára az M0-M6 fóút átvezetése a területen.

Másodikként a Váci út térségében három háztömböt vizsgáltam, ezeken részben lezajlott, részben tervezett folyamatokat mutatok be. Ezeknek a területeknek a városszerkezeti helyzete előnyös, újrahasznosításuk magánkezdeményezés.

A vizsgálatok eredményeit egymással, valamint a nemzetközi gyakorlattal vetettem össze, megállapítva a fôvárosi barnamezők újrafejlesztési gyakorlatában a folyamatokat befolyásoló tényezőket, ezek között például a városszerkezet hatásait és az önkormányzat szerepét.

Kulcsszavak: barnamezős területek, barnamezők megújítása, városi területek újrahasznosítása, kármentesítés, ipari örökség

* egyetemi tanársegéd. BME Építészmérnöki Kar, Építéskivitelezési Tanszék. E-mail: alepel@ekt.bme.hu 


\section{CÉLKITÜZÉSEK}

Az ipar fejlődése, az ipari struktúra változása Budapest városszerkezetének alakulására lényeges hatással volt és van ma is. Nemzetközi, nemzeti gazdasági folyamatok, illetve a módosult igények, technológiai követelmények következtében az ipar szerkezete megváltozott. Korábban hangsúlyos ágazatok leépítése miatt számos gyár zárt be vagy múködik csökkentett kapacitással. E folyamatok eredményeképp nagy kiterjedésü, általában alulhasznosított barnamezős területek alakultak ki a fővárosban.

Tanulmányom célja a budapesti barnamezők „újrafejlesztési” folyamatainak elemzése, az irodalomból megismert külföldi és budapesti gyakorlat összehasonlításával, valamint a folyamatok feltárásával. Be kívánom mutatni, hogy a településszerkezet változása után a további felhasználás lehetőségeinek megállapításához milyen szempontok szerint kell a létesítményeket vizsgálni. Célom az ipar fejlődése és a településszerkezet egymásra hatásainak bemutatása. A folyamatok meghatározzák a különböző intézkedéseket, ezek megismerése pedig a végrehajtás szakszerüségét növelheti.

Tanulmányom az ipari épületek újrahasznosítására irányuló összetett kutatás részét képezi. A kutatás keretein belül a barnamezős területek újrahasznosításának településszerkezeti vonatkozásain túl tanulmányozni kívánom az ipartörténetet, emellett vizsgálni kell az ipartelepeket, az ipari építészetet, ipari épületeket, valamint a hasznosítás gazdaságossági kérdéseit.

\section{BEVEZETÉS}

Ebben a tanulmányban bemutatom az ipar fejlődését és a közelmúlt változásait Budapesten, tárgyalom a várható fejlődés irányát is. Áttekintem az ipar hatását a településszerkezetre, a főváros szerkezetének változásait, az egyes területek módosulását. Budapest földrajzi helyzete, valamint Magyarország gazdaságpolitikája miatt az ország gazdasági központjává vált. A központosítás nem csak az iparban, hanem a közlekedésben, a kultúrában, az oktatásban is megjelent. Különösen szembeötlővé vált ez Pest, Buda és Óbuda egyesítése után. A város szerkezetének kialakulásában döntő jelentőségű volt az ipar, mert az ipari forradalom kibontakozásával egy időben történt Budapest legnagyobb ütemú kiépülése is. A II. világháborúig nem csak a fővárosban, hanem a környező településeken is létesültek ipartelepek.

Ez a tanulmány az ipar fejlődésével párhuzamos településszerkezeti változásokkal, valamint az ipari struktúra módosulásának következtében kialakult barnamezőkkel foglalkozik. Nyilvánvaló, hogy az ipari üzemek felszámolása után az 
ipari létesítmények, épületek közül egyeseket meg kell semmisíteni (pl. erősen szennyezettek), de van számtalan olyan épület is ezeken a területeken, amelyek további felhasználása lehetséges, sőt célszerü, szükséges műemléki védettség vagy gazdasági okok miatt.

\section{AZ IPAR FEJLŐDÉSE BUDAPESTEN}

A II. világháborúig igen változatos ipar telepedett meg Budapesten és a környező peremtelepüléseken, a vezető szerep az élelmiszeriparé lett, de meghatározó volt a nehézipar (gépgyártás, járműgyártás) és egyéb könnyűipari ágazatok (gyógyszeripar, textilipar, villamossági ipar stb.) is. A II. világháború után az államosítás következtében nem a kereslet és a kínálat, hanem a központi döntések határozták meg az ipar fejlődését, a legnagyobb hangsúlyt a nehézipar kapta.

Magyarországon az ipar struktúrája az 1990-es években lejátszódott politikai változás után jelentősen átalakult, az alapanyaggyártó- és nehézipar helyét fokozatosan átvette a feldolgozóipar, a villamos gép-, múszeripari gyártás, és jármúipar, híradástechnikai ipar, gumi-, múanyagtermékek gyártása. Budapesten a vegyipar, a gyógyszeripar, az élelmiszeripar (szeszipar, csokoládégyártás, stb.), vegyipar, villamossági ipar, nyomdák, egyéb könnyü-, és nehézipari vállalkozások kerültek előtérbe [6]. Budapest agglomerációjával a legnagyobb ipari központ maradt. A XX. század legvégén a tercier szektor (szolgáltatások) megerősödése is jellemzővé vált. Az elmúlt évtized ipari fejlődését egyre inkább a külföldi tulajdonú cégek határozták meg. A gyors struktúraváltással nem járt együtt a technológia fejlesztése, így a foglalkoztatottságban a munkaigényes tevékenységek szerepe jelentős maradt, de a relatív bérköltségek emelkedésével a munkaigényesség csökkenése várható.

Az ipar szerepe a foglalkoztatottságban még mindig jelentős. A Magyar Tudományos Akadémia Regionális Kutatások Központja által 2002-ben végzett felmérés szerint az ipari vállalatok a vállalkozások 14\%-át tették ki, a foglalkoztatottak 40\%-a dolgozott iparban. A vegyes tevékenység (ipar, szolgáltatás és/vagy mezőgazdaság) a vállalatok 60\%-ára jellemző. A szolgáltatások közül a legfontosabb a kereskedelem, a szállítás, a raktározás és a közlekedés [2].

Az ipar fejlődését az Európai Uniós tagság is befolyásolja, mert az uniós követelményeknek, célkitűzéseknek megfelelően alakítjuk a további iparpolitikánkat. Ennek megfelelően 2010-ig valószínüleg az infokommunikációs technológiai szektor (számítástechnika, telekommunikáció) térnyerése lesz a meghatározó. Az innováció, a kutatás és a fejlesztés erősítése nem csupán a magas hozzáadott érték miatt fontos, hanem a hazai termékek versenyképessége szempontjából is elengedhetetlen. A hazai iparpolitika célja a kis- és középvállalkozások támogatása. Az elkövetkezendő évek feladatai közé tartozik többek között az infrastruktúra fejlesz- 
tése, a vállalkozói környezet javítása [9]. A fenntartható fejlődés, környezetvédelem előtérbe kerül.

Az előzőekben meghatározott törekvések Budapestre is jellemzőek, így a közlekedés fejlesztése és a környezetvédelem szerepel az elkövetkező 15 év stratégiájában. A fóvárosban is lényeges a vállalkozások hálózatokba szerveződése. „A budapesti gazdaságban ilyen együttmúködő rendszerek, ún. klaszterek formálódhatnak az ipar különböző ágazataiban (gyógyszeripar, gépipar, nyomdaipar), a tudásiparban (felsőfokú oktatás, kutatás, fejlesztés, high-tech iparok összekapcsolódásai), valamint az idegenforgalomban (turizmus és kereskedelmi kapcsolatában). Cél, hogy Budapest a tudásipar és a termelő gazdaság összekapcsolásával minél több területen váljék innovációs központtá" [15]. Ebben a folyamatban hatalmas előnyt jelent a főváros nemzetközi szinten is kiváló elhelyezkedése (európai közlekedési folyosók metszéspontjában).

Az ipar struktúrájának ilyen átalakulása egyértelmúen befolyásolja Budapest településszerkezetét. Az ipari területeken az új ipari tevékenység mellett egyéb tevékenységek is megtalálhatók. Ezt mutatja az is, hogy a barnamezős területeken a foglalkoztatás alapján a legnagyobb súllyal az ipar jelenik meg (a foglalkoztatottak 41,7\%-a) a különböző szolgáltatások (kereskedelem 10,0\%, szállítás, logisztika $22,6 \%$, egyéb szolgáltatás $24,6 \%$ ) előtt [2].

\section{A TELEPÜLÉSSZERKEZET VÁLTOZÁSA, ÁTALAKULÁSA}

A céhes, majd a manufakturális ipar a lakóterületek közelébe települt, ez volt jellemző Pest Buda és Óbuda külső területeire, amelyek ma már belvárossá váltak. Ezek az ipari területek a város terjeszkedése során lakóterületekké alakultak, az ipari épületeknek nagy részét már az I. világháború előtt lebontották.

Az ipari forradalom kibontakozásával a fejlődő iparnak egyre több területre volt szüksége. A belső kerületekben sok kisebb üzem volt a lakóterületekkel keveredve, a nagyobb gyárak a külső kerületekben helyezkedtek el. A XIX-XX. század fordulója után a nagyléptékủ fejlődés nyomán csaknem teljesen kialakultak a főváros hagyományos ipari körzetei:

- A pesti északi ipari terület, ez Újpesttől a Nagykörúton belüli Lipótvárosi területekig terjedt, jellemzőek voltak a nagy gyárak, valamint a lakóterületek közé ékelődött kisebb üzemek;

- A Józsefvárosban a Kerepesi temető mögött és a Józsefvárosi pályaudvar mellett;

- A déli ipari övezet elsősorban a Soroksári út mentén terült el;

- A kőbányai ipari terület a Kőbányai út mentén feküdt, és elérte a VIII. kerületet; 
- Óbudán a Hajógyári szigeten és a lakóterületektől északra;

- A II. kerületben a mai Bem József utca környékén és a Margit körút mögött;

- Lágymányos déli részén a Duna és a Fehérvári út között;

- A peremközségekben: Újpesten, Csepelen, Kispesten, Erzsébetfalván, Pestlőrincen, Budafokon.

A két világháború közötti fejlődés egyenes folytatása volt az I. világháború elöttinek. A város és a peremtelepülések növekedésének hatására csaknem összefüggő ipari övezet alakult ki (1. ábra).

A II. világháború után elvégzett újjáépítés tartósította azt a városszerkezeti hibát, amit a belső és külső lakóterületek közé ékelődő ipari területek okoztak, mivel az elpusztult üzemek kitelepítése nem történt meg. Az új ipari munkahelyeket a la-
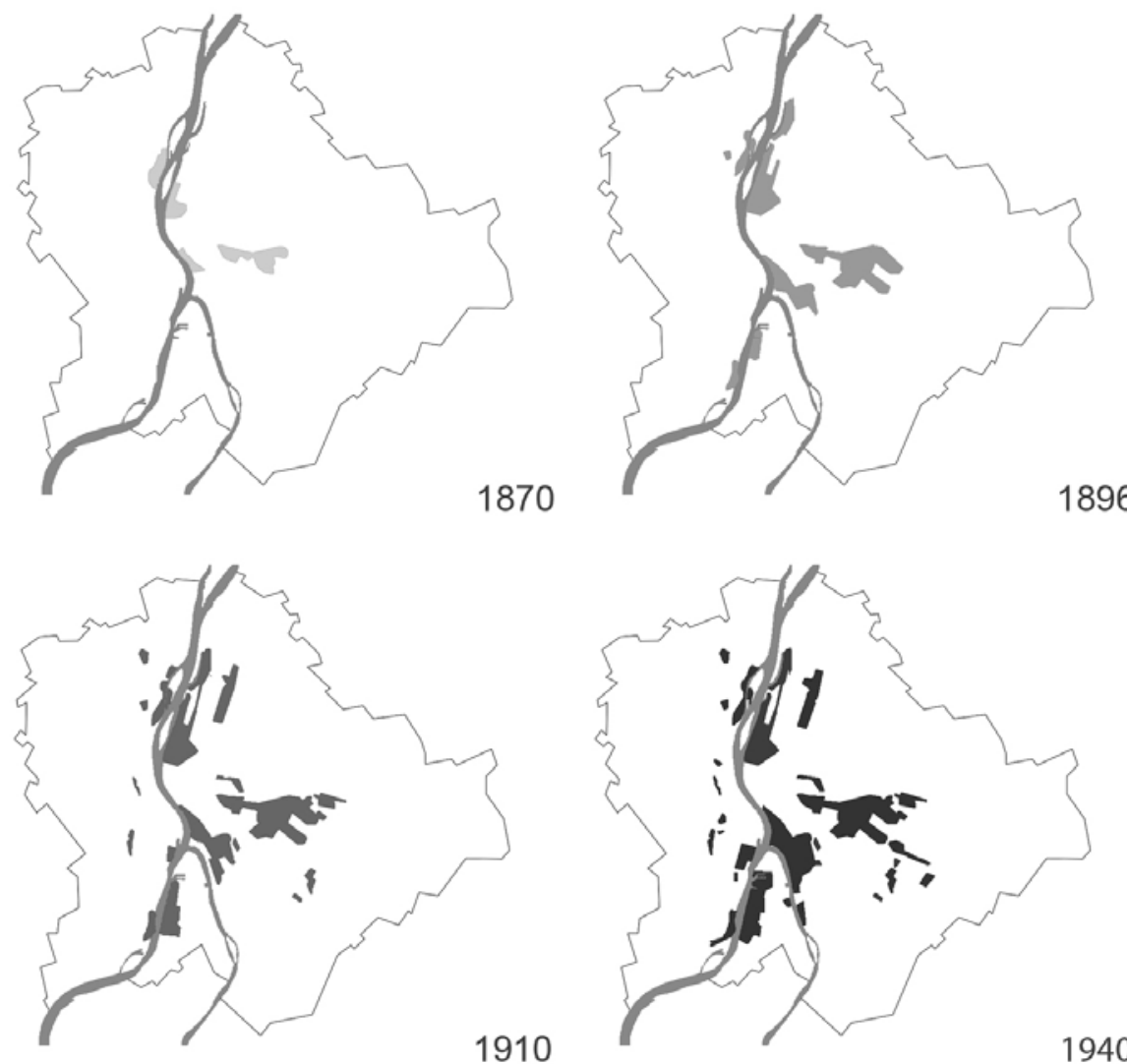

1. ábra. Budapest ipara 1870 körül, a millennium idején, 1910-ben és 1940-ben - amelyik képnél nem jelöltük meg a forrást, azt a szerző készítette 
kótelepek közelébe telepítették, ennek hatására új ipari területek keletkeztek. Az ötvenes években ipartelepítés többek között Rákospalota, Rákosvölgy, Kőbánya, Nagytétény és Óbudai ipari célra kijelölt területein történt. 1970-ben újabb ipari területeket jelöltek ki Óbudán, Rákospalotán, a Jászberényi út, a Cinkotai út valamint az Ócsai út mentén. Zöldmezős beruházások leginkább a raktározás és a szolgáltatóipar területén történtek, egyébként inkább a meglevő telepek bővítése, felújítása-korszerúsítése volt a jellemző [12].

A hazánkban az 1990-es évek elején lezajlott rendszerváltozással együtt végbemenő gazdasági átalakulás igen nagy hatással volt Budapest iparszerkezetére. A privatizáció során az állami vállalatok, ezzel együtt az ipari területek magánkézbe kerültek, felaprózódtak. E folyamat során olyan helyzetek jöttek létre, amelyek a további fejlesztéseket igencsak hátráltatják (pl. több - gyakran a sokadik tulajdonosváltás miatt ismeretlen - tulajdonos kezében levő ingatlanok, használhatatlan arányú telekrészek, épületeket félbevágó telekhatárok, telkeken áthaladó közmúvek stb.). Az ipari területek infrastruktúrájának évtizedeken át elmaradt felújítása, karbantartása miatt az épületek lepusztultak, a közmüvek elöregedtek. A talaj szennyezettsége egyes esetekben bizonyított, más helyeken csak feltételezett, kármentesítésre általában nem került sor (2. ábra).

Egyes területek, főleg a jó közlekedési potenciállal rendelkező ipari területek megújulása megindult, itt jellemzően kereskedelmi- és irodaépületek jöttek létre. Összefogott, jól sikerült hasznosítás történt a Millenáris Park esetén, ahol kulturális funkció kapott helyet, vegyes funkciókat telepítettek a MOM Parkba, valamit a Millenniumi városközpontnak nevezett területre a Petőfi híd és a Lágymányosi híd között. Sikeres példaként említhető továbbá a Váci út két oldalán, egyes kőbányai területeken végbement megújulási folyamat. A belvároshoz közeli, jó tömegközlekedési kapcsolatokkal rendelkező területeken lakások is épültek. A belső, nehezen elérhető telkeken nem történtek ilyen mértékủ beruházások, e területeknek ma kis befektetéssel való újrahasznosítása figyelhető meg (kereskedelmi, raktározási vagy termelési céllal). A fóvárosi városfejlesztési politika az ipari területekkel kapcsolatban a következőket mondja ki: városszerkezetben kedvezőtlen elhelyezkedésű, valamint leromlott állapotú iparterületek területhasználati és/vagy technológiai funkcióváltása nélkülözhetetlen. Emellett a szükséges ipari tevékenységeknek helyet kell adni. A Település Szerkezeti Tervben ezek a területek iparterületként, munkahelyi területként szerepelnek.

Az egykori ipari területek hasznosítása 2002-ben a következő arányok szerint alakult: ipar - 13,3\%, vegyes használat - 41\%, szolgáltatás - 36,9\%, egyéb hasznosítás $-6,4 \%$, használaton kívüli terület $-2,3 \%$. A barnamezős területeken szinte az összes épület használatban van, de a használat intenzitása jellemzően alacsony. A hasznosítatlan épületek aránya ágazatonként változó, legalacsonyabb a kereskedelemben $(0,83 \%)$, közepes az iparban $(2,28 \%)$, kicsit magasabb a logiszti- 


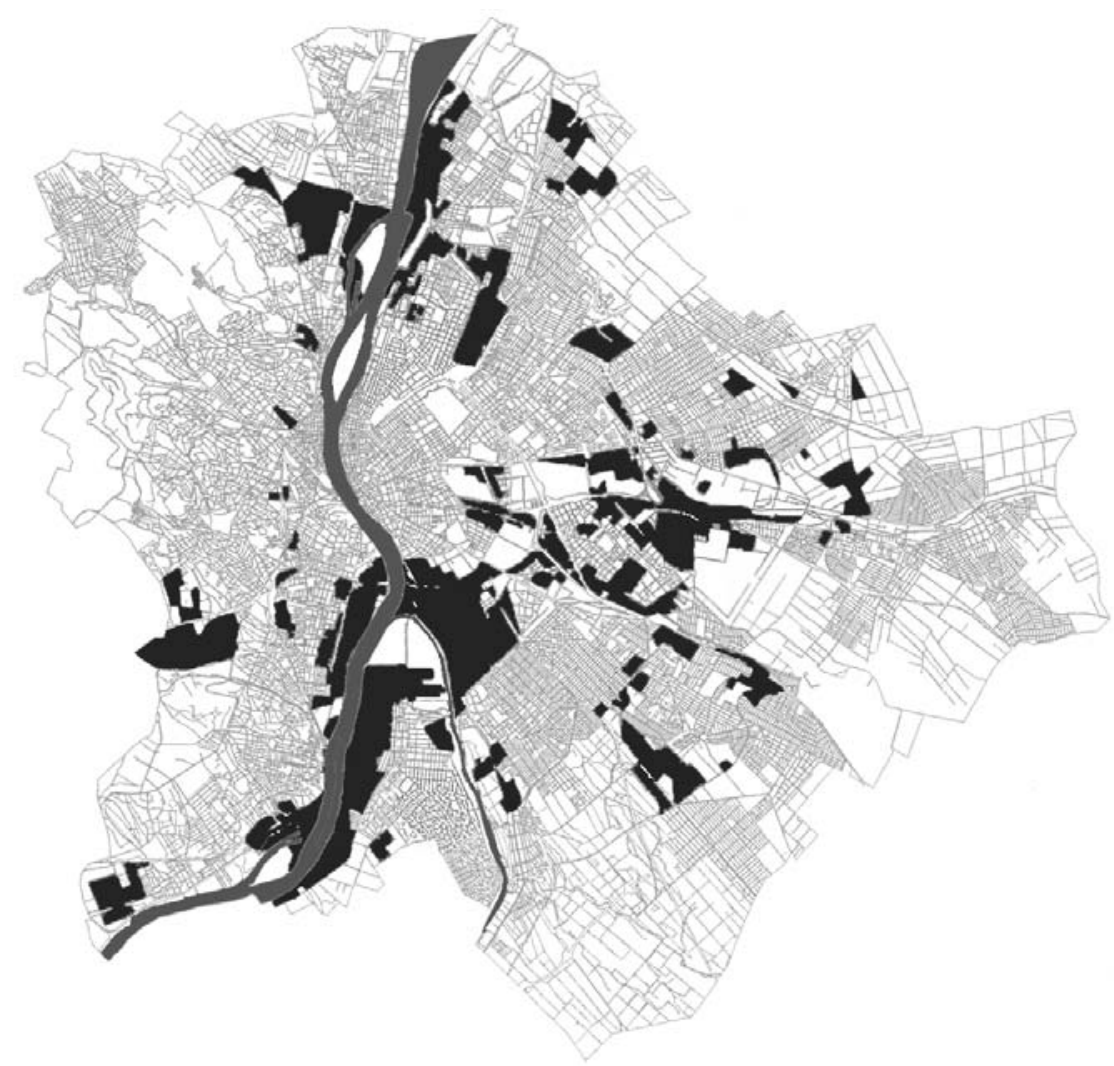

2. ábra. Barnamezős területek Budapesten

kai, raktározási vállalatoknál (3,07\%), a legmagasabb az irodai funkció esetén $(4,84 \%)[2]$.

A fôváros városfejlesztési koncepciója Budapest területét a következő szerkezeti zónákra osztja: hegyvidéki zóna, belső zóna, Duna menti zóna, átmeneti zóna, külső zóna (3. ábra). Egykori ipari területek jellemzően a Duna menti zónában, valamint az átmeneti zónában találhatók. A fóváros távlati elképzeléseiben a Duna menti zóna elsősorban a városközpont tengely irányú fejlesztésével, valamint a város és a folyam kapcsolatának erősítésével, pl. vízi sport területek kialakításával, idegenforgalom fejlesztésével kapna új arculatot. Ennek során elsősorban intézményi és sport, rekreációs és szabadidős területek, zöldterületek kapnának helyet a zónában. E koncepció megvalósulása során a térség alulhasznosított területei is felértékelődnének. Az átmeneti zóna barnamezős területeinek megújulása nagyban függ elérhetőségüktől, közlekedési kapcsolataiktól. A városfejlesztési kon- 


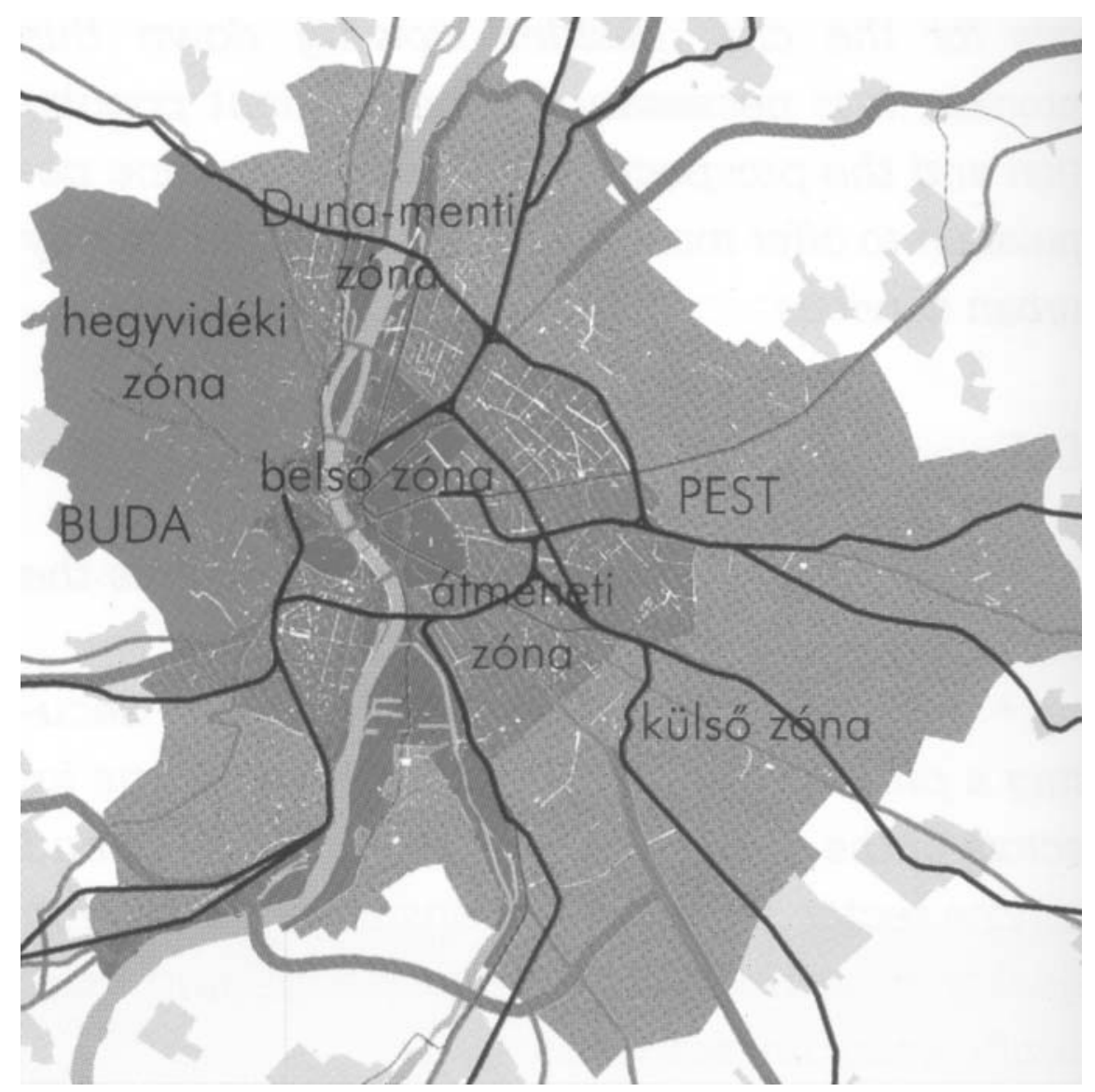

3. ábra. Budapest felosztása az öt zónára - forrás: Budapest Városfejlesztési Koncepció (összefoglaló)

cepcióban szereplő Körvasúti körút feltárná a belső területeket, ezzel fejlesztési szempontból kedvező helyzetbe hozná azokat. A körút megvalósítása északon a 10-es fóút és az M3-as autópálya közötti szakaszon az Aquincumi híd felépítésével kezdődhet el. A déli szakasz kialakítására csak később kerülhet sor. A hídépítésre a Csepel-sziget feltárása érdekében is szükség lesz. [15]

Cél az, hogy a fejlesztők figyelme a zöldmezőkről a barnamezőkre forduljon. Ezek a területek lehetőséget teremtenek olyan vegyes használatú térségek kialakítására is, amelyek a területek alközpontjának szerepét is megkaphatnák. A vegyes területhasználat a megújuló gazdasági funkciók mellett új lakásépítési, irodai, valamint rekreációs és zöldterületek kijelölését jelenti. E területek újrahasznosítása során a főváros zöldterületi hálózatának bővítése is megtörténhet. Az átmeneti zó- 
nában az iparterületek átalakulása, városiasodási folyamat várható, ehhez azonban egy átfogó fejlesztési koncepció kialakítása szükséges. A főváros szabályozó, előkészító valamint koordinációs szerepet tölthet be a folyamatokban. „A budapesti városrehabilitációnak ezért fontos célkitűzése a rozsdaövezetek koncepciózus reorganizációja, újrafejlesztése, amely egyrészt az ott működő kis- és középvállalkozások fejlesztéseinek, tulajdoni rendezésének támogatását, másrészt pedig a közterületek megújítását, a terület vonzerejének növelését igényli a közhatalom részérôl." [3]

\section{BUDAPEST BARNAMEZŐS TERÜLETEINEK MEGÚJULÁSA}

A fővárosi barnamezős területek közül két helyszínt választottam a konkrét vizsgálatok tárgyául: a nagytétényi egykori Metallochemia területét és az angyalföldi Váci út térségét. A példák kiválasztásában szerepet játszott a területek városszerkezeti helyzete, annak különbözősége, azaz a területek belvárostól való távolsága és megközelíthetősége. Kiválasztási szempont volt még a megújulás körülményeinek különbözősége, szennyezettségi, beruházási kérdések.

A bevezetőben leírtak szerint a Fővárosi Városfejlesztési Koncepcióban szerepel, egyes területeken meg is kezdődött a barnamezős területek újrahasznosítása, megújulása. A munkahipotézisek szerint a főváros két különböző (városszerkezeti szempontok szerint is eltérő) pontján a barnamezős területek újrahasznosítása lényegesen különbözik: míg a központtól igen nagy távolságra levő nagytétényi telek megújítása állami pénzből, az eredeti létesítmények teljes megsemmisítésével megy végbe, addig a belvárossal jó közlekedési kapcsolatban levő területeken fokozatos, egyes épületeket hasznosító, magántőke felhasználásával történő megújulás figyelhető meg.

\section{A BARNAMEZŐS TERÜLETEK ÚJRAHASZNOSÍTÁSÁNAK VIZSGÁLATI SZEMPONTJAI}

A barnamezős területek sorsát egyrészt a terület (telek, tömb) tulajdonságai, másrészt a településszerkezet és annak változásai határozzák meg. Ezért szükséges a főváros szerkezetét, a barnamezős területek sorsát befolyásoló tényezők feltárása az alábbiak szerint:

- A településszerkezet változásait meghatározó tervek vizsgálata (fóvárosi településszerkezeti terv, fővárosi szabályozási keretterv, kerületi szabályozási tervek);

- Az érintett területek övezeti besorolása és ennek következményeinek vizsgálata; 
- Az önkormányzatok (fővárosi, kerületi) fejlesztési céljainak, eszközeinek megismerése;

- A területek múszaki tulajdonságainak (méret, tájolás, szomszédok, terep- és talajviszonyok, stb.) szerepe;

- A terület városszerkezeti helye, a várható funkciók igényei (közlekedés, parkolás, közmúellátottság, intézményi kapcsolat) biztosítottak-e;

- A terület elvi és gazdasági értékének meghatározói, súlyuk a fejlesztési döntésben.

\section{NAGYTÉTÉNY: METALLOCHEMIA}

\section{Ipartörténet, az ipartelep vizsgálata}

A Metallochemia elődjét 1908-ban alapította Lossinszky Imre Újlipótvárosban (Rudolf rkp. 4.). A Magyar Ónművek 1910-ben Nagytéténybe, a település belterületétől 1,5-2 km-re létesített, a vasútvonalak, a Duna és a lakóterületek relatív kis távolsága miatt előnyös elhelyezkedésủ területre költözött. Színesfém-hulladék feldolgozásával foglalkozott, később a kohászat mellett vegyipari tevékenységet is végeztek, a korai munkás-létszám 50-60 fő volt. A cég gazdasági szerepe az I. világháború nagy színesfém-igénye miatt jelentősen megnőtt, „,mondhatni az iparág uralkodójává vált" [18]. 1920-ban a társaság átalakult a Magyar Ónmüvek, Fémkohó és Vegyipari Részvénytársasággá, tőle bérelte a területet 1921-től 1935-ig az „Orion” Rézkohó és Rézgálicgyár Rt., az ebből a korból származó térképen a területet mezőgazdasági területek vesznek körül (4. ábra). Az I. majd a II. világháború között az ólom- és rézkohászat vált a legfontosabb tevékenységgé, emellett készültek itt ólom-félgyártmányok, festékek, egyéb vegyipari termékek is. A II. világháború során az üzem, annak berendezései jelentősen nem sérültek meg. Az 1950-es államosítás után a cég önálló vállalatként mưködött tovább, a főbb gyártmányai négy csoportra oszthatók:

- kohótermékek (pl. konverter vörösréz, finomított ólom, kohóezüst stb.);

- ólom-félgyártmányok;

- kénsavas-kénessavas sók (pl. rézgálic, krómtimsó, cinkszulfát stb.);

- vegyi por (fém-)festékek (pl. ólommínium, horganyfehér, lithopon stb.) [18].

Az 50-es évektől jelentősen bővítették az üzemet, a telephely területe az egykori 1 hektárról fokozatosan 20 hektárra nőtt, ebben a korban a maximális munkáslétszám elérte a 750 fôt. 1964-től a vállalat a Csepel Mủvek Tröszt vállalataként müködött, majd a Csepel Művek átalakulása miatt 1976-tól a Csepel Művek Fémmü 


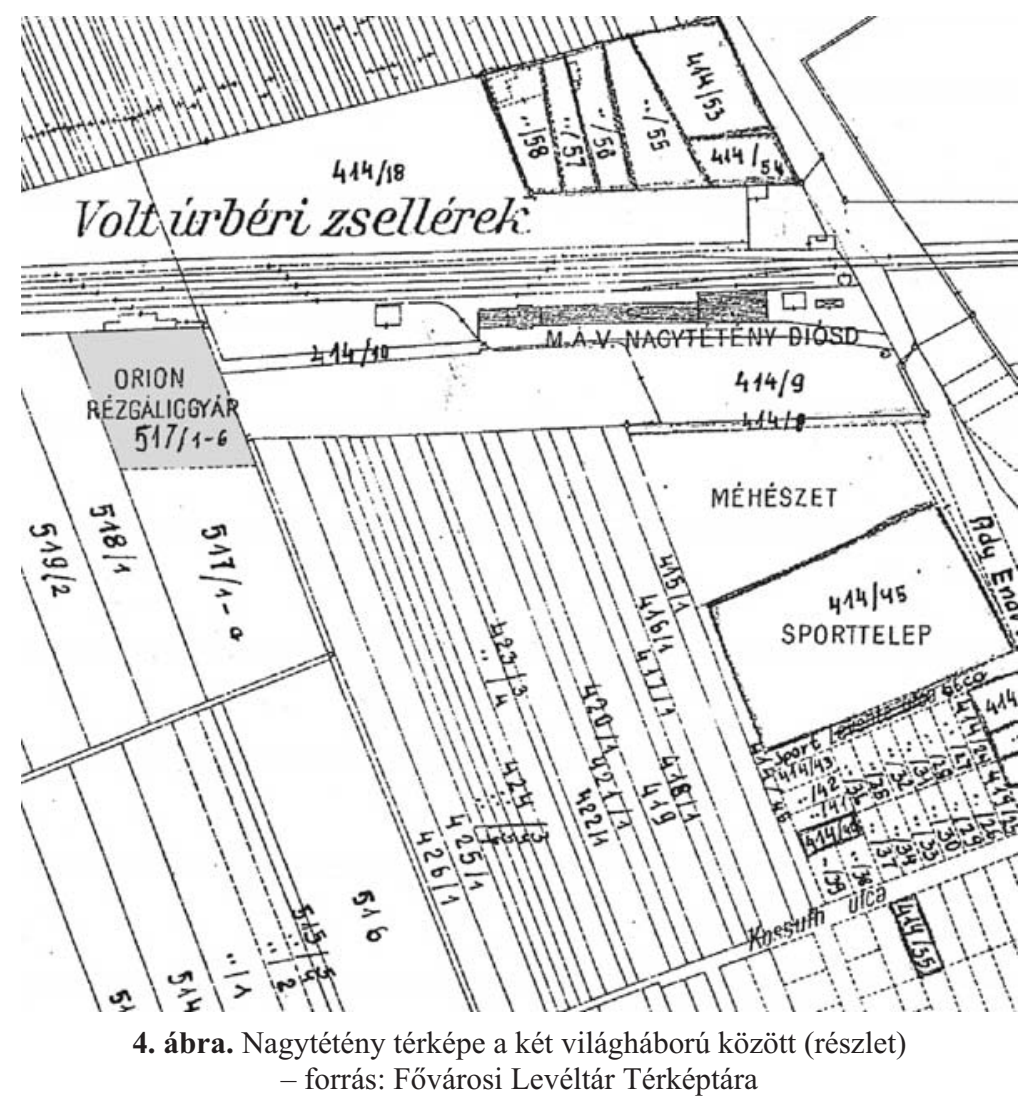

Gyáregysége lett. 1976-ban leállították a legjobban szennyező tevékenységeket: az ólomkohászatot és a konverteres rézgyártást, az ehhez kapcsolódó épületeket lebontották. 1977-ben környezetvédelmi beruházások után újraindult az aknás rézkohászat, a szennyezőanyag-kibocsátás ekkortól döntően a határértéken belül volt. Ekkor indult meg a telephelyen az akkumulátorok törése és savtalanítása, az itt elökészített akkumulátorokat vasúton az NDK-ba szállították. A technológiai fejlesztésekkel párhuzamosan a II világháború után új épületeket hoztak létre, jelentős részüket az 1970-es években építették, a régi csarnokokat a 60-as, 70-es években lebontották. A gyáregység 1983-ban került a Metalloglobus tulajdonába [13]. Az üzem múködését 1990. május 25-én függesztette fel a KÖJÁL, majd a gyárat rövidesen bezárták, ezután közel másfél évtizedig üresen állt [9] (5. ábra).

A 80 éves működés során 980000 tonna, $410000 \mathrm{~m}^{3}$ kohósalak halmozódott fel a területen. A környezetszennyező tevékenységek nyomán a talajba illetve talajvízbe nehézfémek és ezek sói, legnagyobb mennyiségben ólom, kadmium, réz, cink került. A szálló por miatt nem csupán a telephely, hanem a környező telkek ta- 


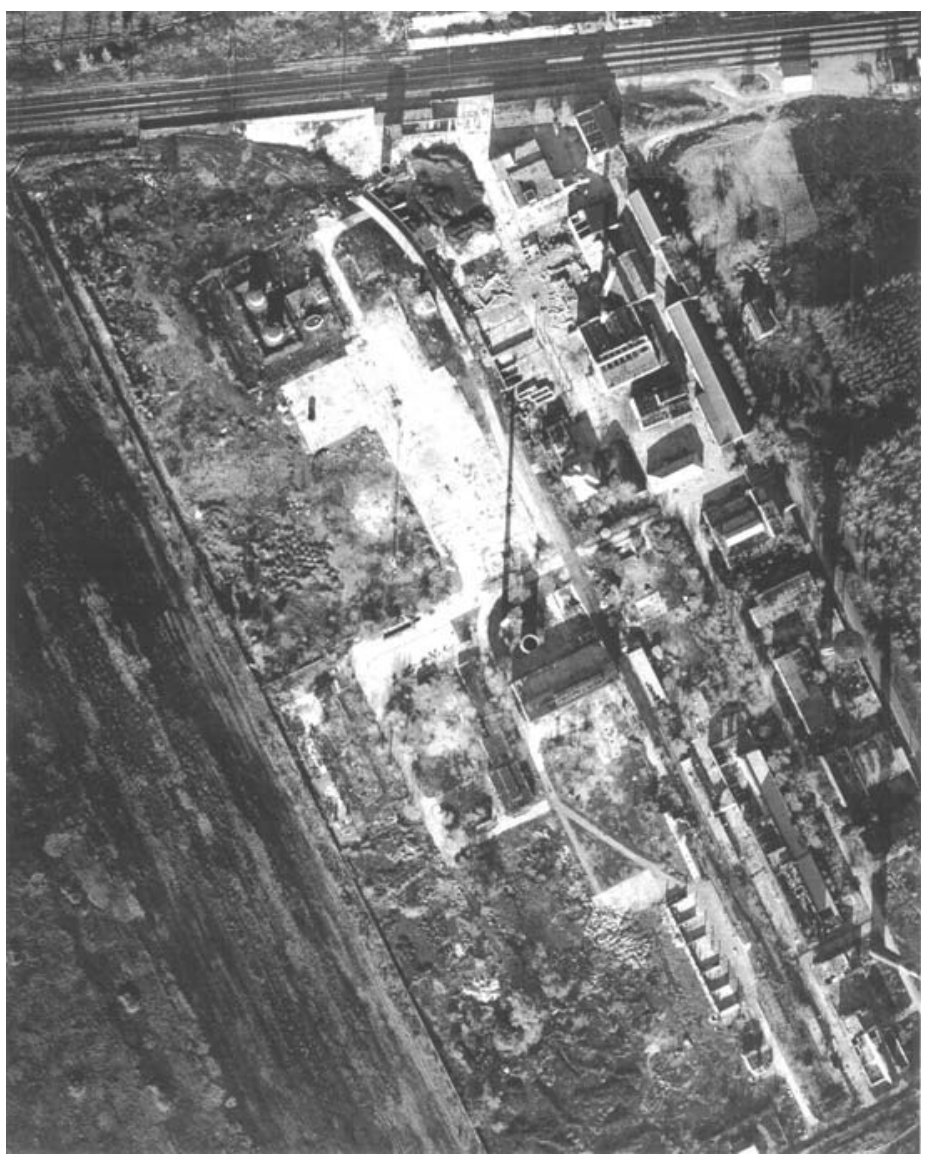

5. ábra. Légifotó a Metallochemiáról 2001-ben - forrás: Repét Kft.

laja is szennyeződött. 1990 óta 13 különböző terv készült a terület kármentesítésére, de a munkálatok nem indulhattak meg, mivel a Metalloglobus Rt. a felelösség mértékének megállapítását bíróságra bízta. A végül elfogadott terv keretét az Észak-Magyarországi Környezetvédelmi Felügyelőség 8932-94/1999. sz. határozata adja. „A határozat a „salak-meddő mozgatás nélküli helybenhagyással történő „szarkofág”-szerű lefedését”, a talajvíz és a salakdepónia érintkezésének kizárását folyamatos talajvízszint-süllyesztéssel vagy résfalas körbezárással írja elö” [14]. A kármentesítés állami finanszírozására 2004. március 31-én született kormányhatározat, a költségeket a Gazdasági és Közlekedési Minisztérium, a Környezetvédelmi és Vízügyi Minisztérium biztosítja. A tervet 2002-ben engedélyezte a Közép-Duna-völgyi Környezetvédelmi Felügyelőség, a kivitelező kiválasztása pedig 2004. októberében meghívásos közbeszerzési eljárás keretében történt. 
A telephelyen $410000 \mathrm{~m}^{3}$ kohósalak van 1-5 m vastagságban elterítve, ehhez még nagy mennyiségű szennyezett talaj, illetve bontási hulladék járul. Az érintett 1400 lakótelekről 20-200 cm mélyen el kell távolítani a károsított talajt. Ez összességében kb. $1200000 \mathrm{~m}^{3}$ szennyezett anyagot jelent.

A kármentesítés technológiája, mely a későbbi használattól, a szennyezettség mértékétől és a talajviszonyoktól is függ, a terület egyes részein eltérő:

- A telek egyik a felén az agyag elérhető mélységben van, résfalat készítenek, amit bekötnek az agyagrétegbe. A résfallal elzárt részre helyezik el a szenynyezett anyagokat, a salakot, törmeléket $60 \mathrm{~mm}$ szemnagyság alá őrlik. Az anyagok tetejére 2,5 mm vastag HDPE müanyag lemez kerül szigetelésvédelemmel. Ennek tetejére földet terítenek, amelyre növényzetet telepítenek. A kármentesítés munkálatai során készített légifotón jól látszik a résfal vonalvezetése.

- A telek másik felén nincs elérhető mélységben agyag, így a résfalas védelem nem lenne gazdaságosan megoldható. Erről a területről eltávolítják a szennyezett anyagokat.

- A telken jelölték ki az M6-os autópálya vonalát. A vasúti kereszteződés miatt az utat $13 \mathrm{~m}$ magas töltésen kell vezetni, a földmúvek szennyezett anyagok (aprított, tömörített salak) és a telek északi oldalán ideszállított föld felhasználásával készülnek.

- A környező lakótelkeken a talajszennyezést talajcserével szüntetik meg.

A telken az ideiglenesen megmaradt konverter épületben töröüzemet létesítettek, így a szennyezett anyagot nem kell kivinni a területről [16]. A kármentesítés során arra is ügyelni kell, hogy a lakosság és a környező területek védelme érdekében szennyezőanyag szálló por alakban sem hagyhatja el a területet.

\section{A terület újrahasznositása}

A terület újrahasznosítása során az épületek bontása után sor kerül a terület kármentesítésére, majd az üres területet hasznosítják. A mentesítés technológiáját, mértékét rendszerint a leendő funkció figyelembevételével határozzák meg. Az egykori Metallochemia 20 hektáros területének jövőbeni használatát a következőképp tervezik:

- 6,6 ha területet foglal majd el az M6-os autópálya;

- 7,2 ha területet, ahol a szennyezett anyagokat elhelyezik, parkosítanak;

- 4,8 ha mentesített területet ipari, munkahelyi hasznosításra értékesítenek;

- az autópályától nyugatra eső kb. 1 ha mentesített terület sorsa bizonytalan. 


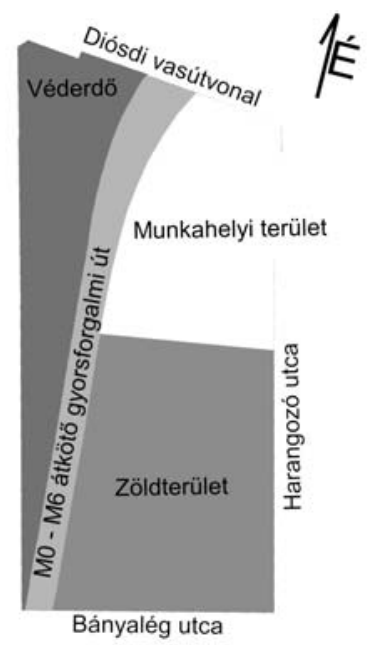

6. ábra. A tervezett területhasználat helyszínrajza - forrás: Vegyépszer Rt.

A beruházás bruttó költsége 12 milliárd forint.

A telek a tervezett területhasználat alapján három részre osztható, a területhasználat intenzitása, hatása a környező területekre karakteresen különbözik a három rész esetén (6. ábra).

Az, hogy az autópálya nyomvonalát a telken vezetik keresztül, több szempontból is előnyös. Egyrészt, az állami tulajdonú telek használatával nem szükséges magántelkek kisajátítása, ez gyorsítja az eljárást. Másrészt a barnamezős terület felhasználása azt jelenti, hogy nem zöldterületen építik az úttestet. Az autópálya közelsége a környező területek használatára is hatással lehet: a könnyü elérhetőség előnyt jelent minden funkciónak, különösen kereskedelmi, logisztikai, ipari tevékenységeknek kedvez, de a megnövekedett forgalom a lakóterületek értékvesztését, funkcióváltását is eredményezheti.

A telek harmadának parkosítása szintén több előnyt hordoz. A budapesti városfejlesztési koncepcióban célként jelölték meg a zöldterületek gyarapítását is. Ezzel az intézkedéssel nem csupán a fővárosi zöldterületek gazdagodnak, ráadásul egy korábbi szennyezett barnamezős terület helyén, hanem a zöldsáv az út és a lakóterületek között csökkenti a közlekedés okozta zajt és szennyezést. Barnamezős területek parkosítására jó példa található Torontóban, ahol tíz egykori ipartelep helyét parkosították. A folyamat eredményeiről, a környező lakóterületek komfortjának növekedéséről De Sousa számolt be [5].

A kialakítandó munkahelyi terület városszerkezeti helyzete több szempontból is előnyös: 
- Az épülő autópálya, az M0-ás körgyürú, valamint a meglevő utcák és a vasút miatt kiváló közlekedési kapcsolatokkal rendelkező terület, nem csak városi, országos szinten is;

- A lakóterületek közelsége a munkaerő közelségét is jelenti;

- A városrész jellege, valamint az új parkosított rész kialakítása miatt a terület zöldbe ágyazottá válik.

Ennek megfelelően a terület várhatóan értékes lesz. Mivel ezt a részt teljesen kármentesítik, ezért az eladásnál a szennyezettség nem szerepel értékcsökkentő tényezőként. A munkahelyi terület eladása részben fedezi a kármentesítés költségeit, valamint az ipari, kereskedelmi tevékenység további bevételt jelent a kerületnek és munkahelyeket biztosíthat a kerület lakosainak.

Mindhárom területhasználati mód gazdagítja a környezetet, negatívumnak csupán a megnövekedő forgalom tekinthető, ami környezetterhelést okoz, de ezt a nagyobb forgalom előnyei ellensúlyozni tudják. A nagytétényi terület kármentesítéssel összekötött hasznosítása több fajta előnyökkel jár, akár a telekre, akár a közvetlen, illetve tágabb a környezetre vetítve. A beruházás tehát elöreláthatóan sikeres lesz.

\section{Ipari épületek sorsa}

A telephelyen számos épület állt. Ezek javarészt technológiai épületek, mühelyek voltak, valamint szociális építmények és kultúrház. Az épületek kora, építési technológiája, építészeti értéke eltérő volt. Bár korai tervekben még egyes épületek hasznosításáról is szó volt, de az épületek felületeinek (vakolat, padló stb.) szennyezettsége ezt gazdaságosan nem tette lehetővé. A bontással lehetőség nyílt a telek szabadabb használatára is. Az ipari épületek újrahasznosítása a komplikáltsága mellett a talaj kármentesítését is jelentősen megnehezítette volna. Az üres telek hasznosítása kevesebb kötöttséggel jár, ami előnyt jelenthet. Az egykori Metallochemia épületeit 2004. augusztusában kezdték bontani, csupán pár épület maradt meg, amiket a kármentesítés során ideiglenesen üzemi épületként hasznosítanak. Mivel a telket üres területként hasznosítják, a megújulás nem kapcsolható az egykori ipari örökséghez.

\section{Gazdaságossági kérdések}

A terület kármentesítésére készült költségbecslés, de mivel a szennyezett anyagok mennyisége (különösen a környező lakótelkeken) nem volt pontosan becsül- 
hető, így a tényleges költség csak a munkák befejezésével állapítható meg. Hasonlóan a hasznosításból származó bevételek is csak az értékesítés során rajzolódnak ki pontosan. A korábban leírt előnyök miatt hosszú távon, közösségi szinten a hasznosítás kedvező eredménnyel kecsegtet.

\section{VÁCI ÚT MENTI BARNAMEZŐS TERÜLETEK}

A Váci út teljes hosszán jellemző városszerkezeti változást a következő három példa jól illusztrálja. A Váci út 127-141. valamint a 169-177. közötti tömbjei a lezajlott folyamatok alapján együtt vizsgálhatók. Az egykori Csavargyár - Hőerőmü területének sorsa ettól némiképp eltér, teljes megújulása csak a jövőben várható. A metró építésének idején készült légifotón jól látható, hogy az ipari használat struktúrája mennyire különbözik a lakóházas beépítéstől. Az egykori ipari területek újrahasznosítása erre a problémára is megoldást adhat (7. ábra).

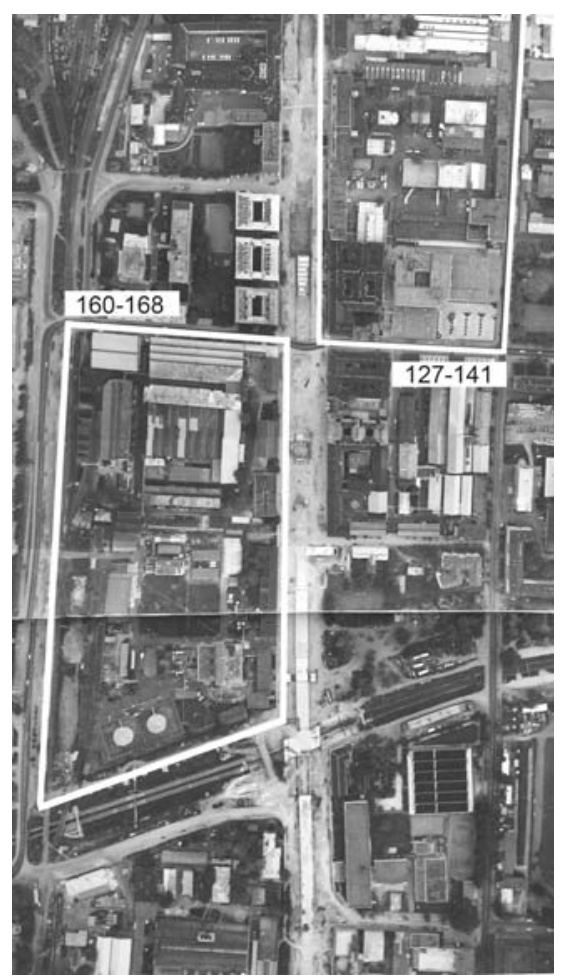

7. ábra. Légifotó a Váci út egy szakaszáról a metróépítés idején - forrás: XIII. kerület Önkormányzat Főépítészi Iroda 


\section{Ipartörténet, az ipartelepek bemutatása}

A Váci út mentén húzódott egykor Budapest egyik legnagyobb ipari területe. A Váci út angyalföldi szakasza több szempontból is kedvezett az ipar megtelepedésének: az 1846-ban megnyitott vasútvonal, a fơút és a Duna kiváló közlekedést biztosítottak, a terület domborzati viszonyai az ipartelepítésre megfelelőek voltak. 1866-tól lóvasút járt a Széna tér (ma Kálvin tér) és Újpest között, ennek hatására felgyorsult az ipar megtelepedése a Váci úton és környékén, 1870-ben már számos gőzmalom mellet a faipar, gépgyártás és egyéb ágazatok is megtalálhatók itt. 1875-re elkészült a Margit híd, épült a Ferdinánd híd, ez újabb gyárakat vonzott a területre. Az élelmiszeripar mellett egyre nagyobb szerepet kapott a nehézipar: gépgyártás, fémmegmunkálás, hajógyártás. A XIX. század végén felépült Újpesti vasúti híd, valamint a budapest-esztergomi vasútvonal és a körvasút kiépülése Angyalföld iparának további jelentős bővülését eredményezte. A I. világháború után sok fémipari üzem megszűnt, helyükre könnyüipar települt [1]. A II. világháborút követően a vállalatokat államosították, egyes üzemeket lebontottak (pl. malmokat), másokat bővítettek (pl. a Láng Gépgyárat) a tervgazdálkodás prioritásainak megfelelően (8. ábra). A rendszerváltozás után megkezdődött a privatizáció, a magánkézbe került gyárak egy ideig még múködtek, de mára többségük bezárt [8]. A tömbökre készült szabályozási tervek egyes épületek megtartását, mások bontását javasolja. Az egykori Láng gépgyár tömbjének szabályozási tervén kiemelt szerepet kapnak a mümelék épületek.

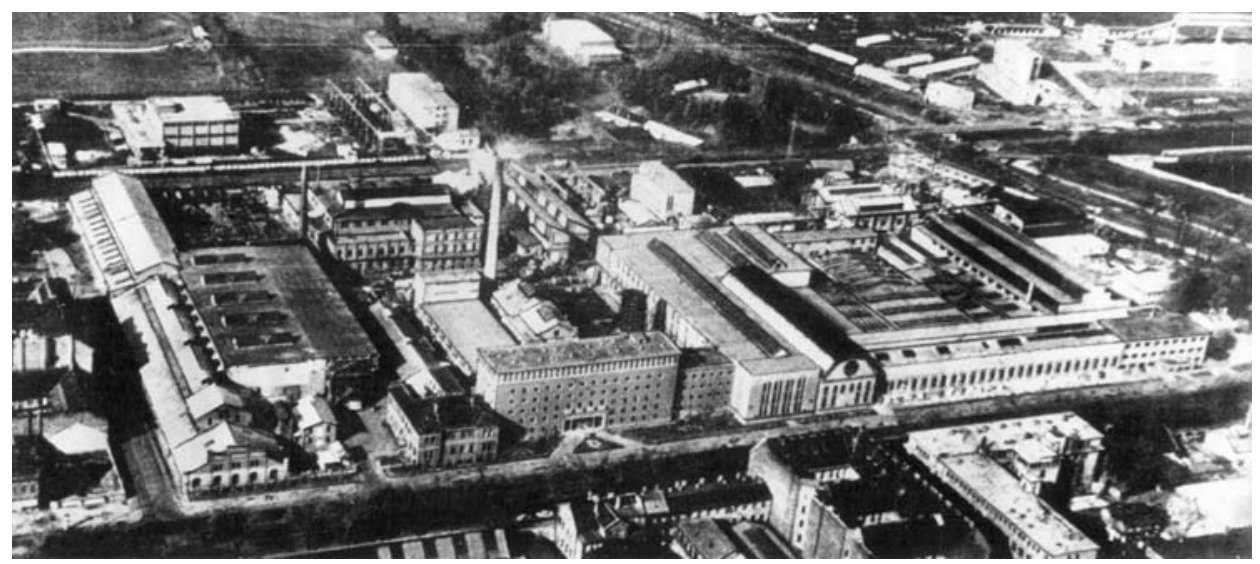

8. ábra. Archív fotó a Láng Gépgyárról

- forrás: Angyalföldi Helytörténeti Múzeum gyüjteménye 
Váci út 127-141., Váci út 169-177.

A Váci út 127-141., illetve a 169-177. házszámok közötti tömbjei korábban a Váci út menti ipari zónához tartoztak, számos gyár, üzem kapott a területen helyet. A Váci út - Szobor utca - Madarász utca - Szekszárdi utca által körülzárt tömb fontosabb gyárai voltak:

- Vatea Villamossági Rt. (Magyar Philips Múvek Rt., Magyar Adócsőgyár, az Egyesült Izzólámpa és Villamossági Rt. Gyáregysége, Tungsram Adócsőgyár) [11];

- Szalag- és Zsinórgyár;

- Magyar Szaruárugyár Rt.;

- Szoborgyár;

- Erőgépjavító Vállalat;

- Cikória-gyár.

A Váci út - Babér utca - Madarász utca - Fiastyúk utca tömb egykori nagyobb üzemei:

- Tudor Accumulátorgyár Rt. (Sirius Múvek Accumulátor és Elemgyár, Akkumulátor és Szárazelemgyár, VBKM Akkumulátorgyár, Perion Akkumulátorgyár Rt.);

- Rothmüller S. Fém és Bádogárugyár Rt. (Magyar Általános Gépgyár, Budapesti Malomépítészet és Gépgyár, Povidecz és Heisler Malomépítészeti és Gépgyár);

- Első Osztr. Jutafonóda és Szövőgyár Rt. (Első Osztrák Jutafonó Gyár, Jutafonó- és Szövőgyár);

- Rico Magyar Kötszermúvek Rt. (Hartmann-Rico Rt.) [1,8].

Közel egy évszázadon át változatos ipari tevékenységek múködtek ezeken a területeken. A cégek méretükben, gazdasági jelentőségükben is különbözőek voltak: pl. textilipari termékeket gyártott a Szalag- és Zsinórgyár, ami 1989-ben 855 föt foglalkoztatott, a Rico Kötszermúvek, 760 alkalmazottal. Az Akkumulátor- és Szárazelemgyár nemzetközi jelentőségü volt, alkalmazottainak száma 1989-ben elérte az 1114 főt. A Vatea Villamossági Rt., majd utódvállalatai színvonalas híradástechnikai termékei nemzetközileg ismertek voltak. A privatizáció nyomán az ipar fokozatosan kiszorult a területekről, ma már csak a Zsinórgyárnak és a Grafika Rt.-nek van engedélye ipari tevékenység végzésére. Az iparban foglalkoztatottak száma már az 1970-es évektől folyamatosan csökkent a fővárosban. Az ipari termelés 1989 és 1993 között bekövetkezett 40\%-os csökkenése újabb elbocsátásokkal járt [7]. A város növekedésével, a belváros terjeszkedésével megkezdődött a 
területek funkcióváltása. Az első irodaházak az 1990-es évek közepén épültek, az egykori ipari épületeket egymás után bontották le.

Ennek a folyamatnak eredményeképpen a tömbök arculata mára megváltozott: új, korszerü irodaházak váltották fel a gyárakat a Váci út mentén. Az irodai funkció mellett megjelent a kereskedelmi funkció is. A Váci úti telkek magas értékét mutatja az is, hogy a 169-177-es tömb Madarász utcai, kevésbé frekventált felén az egykori gyár épületei üresen, elhagyatottan állnak. Az Akkumulátorgyár a tömb teljes mélységét elfoglalta, bontásával így a tömb Madarász utcai fele is megújulhat, a már megkezdődött lakóépület-építés folytatódhat. A telek jelenleg üresen áll, hasznosítását talajszennyezés nehezíti. A belvárostól távolabb eső tömbben régi ipari épületek hasznosítása figyelhető meg, részben funkcióváltással. A belvároshoz közelebbi tömbben a nem használt ipari épületeket már lebontották, ellentétben a másik tömb üres gyárával.

\section{Váci út 160-168.}

Az egykori Hőerőmü, illetve a Csavargyár tömbje szintén a Váci út menti ipari zónához tartozott. A Csavargyár elődjét 1889-ben alapították, neve többször változott: volt Első Magyar Csavargyár Rt., Csavar- és Kovácsárugyár, Brevilier és társa Csavar- és Kovácsárugyár, Brevillier és Fia és Urban A. és Fia Csavar- és Kovácsárugyár, majd a Csavaripari Vállalat 1. sz. Gyára. Ez a gyár hosszú évtizedeken át a kerület egyik legnagyobb üzeme volt. A Csavaripari Vállalat 1988-ig, egyes gyáregységek kiválásáig több mint 1800 fơt alkalmazott. Épületei több ütemben épültek, többször átépültek. A területen volt még a Brunner Testvérek Lágyvasöntödéje is [8], ez egy idő után beolvadt a Csavargyárba (9. ábra).

A hőerőmüvet a II. világháború után telepítették a Váci út és a Rákos-patak által határolt telekre. A szén, majd gázüzemü berendezések a budapesti hálózatba termelték az elektromos energiát. A két ipartelep között húzódott a Csele utca, ami a telephelyek terjeszkedésének áldozata lett. A rendszerváltás után a területen az ipari tevékenység megszünt, az egykori Csavargyárat kereskedelmi funkcióval újrahasznosították.

A Csavargyár épületeiben jelenleg a Reno Udvar kereskedelmi létesítményei müködnek. A névadó cipőüzleten túl található itt élelmiszerbolt, barkácsáruház, egyéb üzletek és szolgáltatások. A kereskedelmi és a további vállalkozások bérlik a helyiségeket. Az épületeket részben felújították, leginkább belső átalakításokat végeztek. A jellegzetes ipari épületek állapota rossz, a telep képe rendezetlen, a telken belüli közlekedés, parkolás kusza. A hőerőmú épületei üresek, kiadásra várnak. A kereskedelmi funkció szükséges, a környéken folyó fejlesztések alapján a kereslet növekedni fog. A Csavargyár területén a kapacitás a jelenlegi formában 


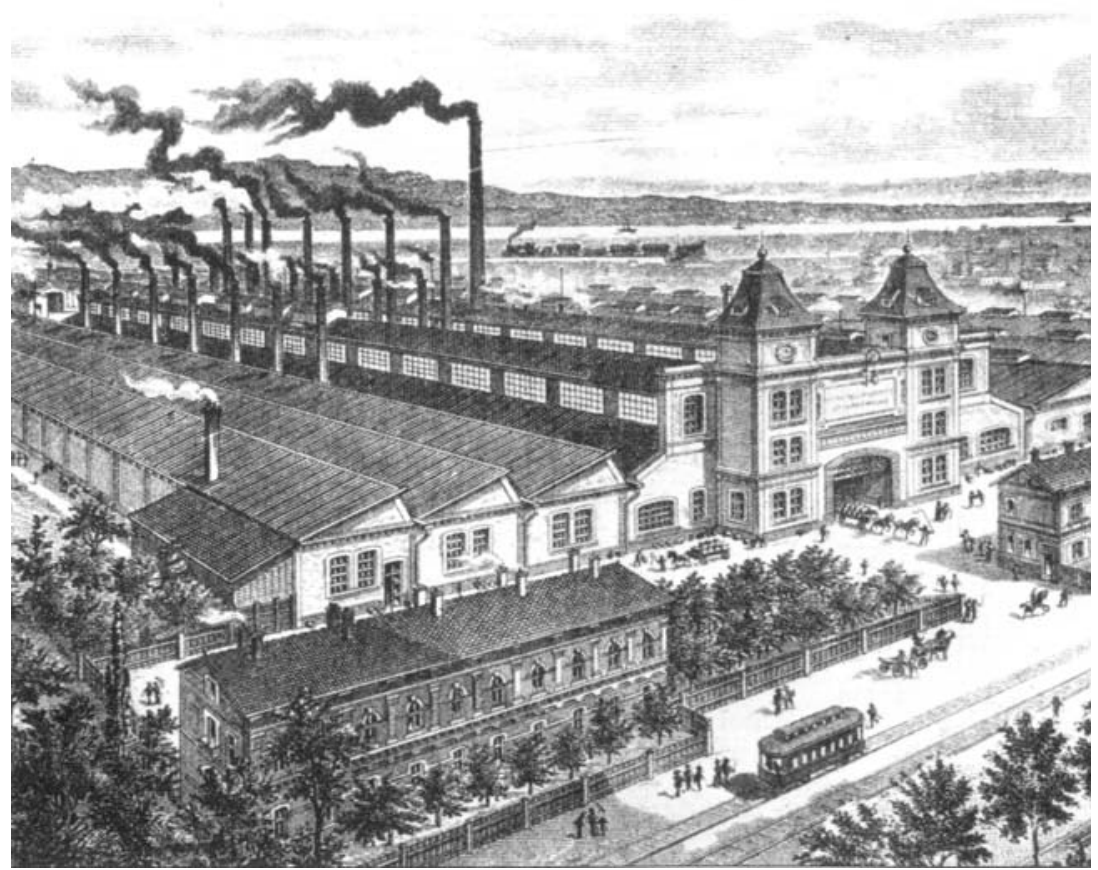

9. ábra. Archív kép a Csavargyárról - forrás: Angyalföldi Helytörténeti Múzeum gyüjteménye

nem bővíthető, a felhagyott ipari épületekben kialakított üzlethelyiségek nem tudnak versenyezni az új építésü bevásárlóközpontokkal.

A Hőerőmü épületeinek a hasznosítását erősen korlátozza az egykori technológia, illetve a technológiai követelmények miatt kialakított speciális tér. A megújulást tovább nehezítheti, hogy a területen talajszennyezés valószínúsíthetö.

\section{Az egykori ipartelepek újrahasznositsa}

Az egykori ipari épületek, telephelyek újrahasznosítása a magántőke vezetésével, piaci kereslet alapján ment végbe. A megújulást, funkcióváltást elősegítette a városon belüli kedvező elhelyezkedés: a Váci út a belvároshoz viszonylag közel van, gépjármúvel, metróval jól megközelíthető. A területen található funkciók szerint kétféle folyamat figyelhető meg:

- A területek funkciójának megtartása (azaz az ipari termelés folytatása), ez történhet az épületek megtartásával, felújításával, vagy bővítésével; 
- A területek funkcióváltása, jellemzően irodai, kereskedelmi vagy lakófunkció kialakításával, ez történhet:

- az épületek bontásával, a terület hasznosításával,

- az épületek megtartásával, a funkcióváltással járó minimális beavatkozásokkal, felújítással,

- a terület megújítása a történeti (valamely szempontból értékesnek ítélt) épületek színvonalas felújításával.

A Váci úti telkek a jó városszerkezeti helyzetük miatt igen értékesek, hasznosításuk éppen ezért jellemzően funkcióváltással jár, az ipar lassan teljesen kiszorul a területről.

A Település Szerkezeti Terv funkcionális szerkezetet bemutató tervlapján a Váci út mentén ,városszerkezeti jelentőségú átalakuló területeket tartalmazó területi egység"-et jelölnek. A vegyes városias használat mellett funkcióváltó gazdasági területek találhatók itt. A városfejlesztési koncepció célja a belvárosi funkciók kiterjesztése északi irányban, a Váci út és a Duna szerepének erősítésével. A meglevő infrastruktúra ezt lehetôvé teszi, és a megindult folyamatok is ebbe az irányba mutatnak. A területre készült tervek a szerkezeti tervtől a szabályozási tervekig szintén ezt a folyamatot támogatják.

\section{Váci út 127-141., Váci út 169-177.}

A területekre jelenleg érvényben levő tervek támogatják az irodaépítési projekteket. A megadott keretövezetek (intézményi illetve intézménydomináns munkahelyi terület) elsősorban közösségi, igazgatási, ellátási és irodai funkciók elhelyezésére szolgálnak, de a lakófunkció is megengedett. Önkormányzati rendelet tiltja lakóhelyiségek Váci út felé nyitását, ezért a tömböknek csak a Madarász utca felőli felén várható ilyen funkció. A beépítési arány, megengedett legnagyobb homlokzatmagasság valamint a szintterületi mutatók intenzív területhasználatot tesznek lehetôvé. A belvároshoz közelebbi tömbben az általánosnál magasabb a megengedett szintterületi mutató (általában 3, itt $4 \mathrm{~m}^{2} / \mathrm{m}^{2}$ ), a telkek kapacitása ezáltal nagyobb. Az élhetőbb környezet kialakítását célozza a minimálisan 20\% kialakítandó zöldfelület. Az egykori Akkumulátorgyár telkén egy összefüggő legalább $40 \times 40$ méteres teljes értékű zöldfelületet kell kialakítani. A zártsorú beépítés és a minimálisan meghatározott építménymagasságok, homlokzatmagasságok a terület nagyvárosias megújulását teszik lehetővé, miközben a már kialakult arculathoz is illeszkednek [4].

A tervek és a megindult folyamatok tehát azt valószínűsítik, hogy a két tömb megújulása hasonló forgatókönyv szerint fog lezajlani, legfeljebb időben kissé el- 
tolódva. Várható, hogy a Váci út mentén a még meglevő ipari, illetve lakóépületeket lebontva végig irodaházak épülnek majd fel, míg a tömbök másik felén lakófunkció kap majd helyet. Ezzel a területhasználat intenzitása nő, a Váci úti telkek gazdasági aktivitása erősödik. A területre költöző funkciók igényei a térségben kielégíthetők, hiszen az irodai (munkahelyi), illetve intézményi, szolgáltatói funkciók elsősorban jó megközelíthetőséget igényelnek, míg a lakófunkciók esetén a közlekedési feltételek mellett épp a szolgáltatások (intézmények, kereskedelem, szórakozás) közelsége az egyik leglényegesebb szempont.

Váci út 160-168.

A jelenleg érvényes szabályozási terv a területre 2000-ben készült. A terv a tömbökre többfunkciós városi használatot jelöl ki (intézményi terület), ennek megfelelően létesíthető a területen iroda- és kereskedelmi funkció, építhető közintézmény, kulturális, egészségügyi, oktatási épület, sportlétesítmény, vendéglátás és szálloda, egyéb szolgáltatások. A terület két telek, ezek az ipari épületek elbontása után megoszthatók. A szabályozásban engedélyezett 60\%-os beépítettség és 3 $\mathrm{m}^{2} / \mathrm{m}^{2}$-es szintterületi mutató az előírt zártsorú-szabadonálló beépítéssel intenzív városi beépítés kialakítását teszi lehetővé. A terület teljes közmúvesítését a fejlesztés előtt biztosítani kell. A közlekedés javításának érdekében a szabályozási terv tartalmazza a Csele u. megújítását. Védett épület nincs a területen, de a terv a Csavargyár kapuépületét városképi jellegzetessége miatt megtartani javasolja. Mindkét tömb régészeti lelőhely, ez késleltetheti a megújulásukat. A szabályozási terv alátámasztó munkarésze javasolja a ,felhagyott ipari épületek átmeneti hasznosítása" helyett új beépítés kialakítása mellett a jellegzetes ipari csarnokok hasznosítását, az értékes ipari homlokzati elemek méltó megmutatását [4] (10. ábra).

A területre a közelmúltban fejlesztési terv készült. A fejlesztési terv a két telektömböt együtt kezeli, és két-két telekre osztja. Az elképzelések megvalósításához új szabályozási tervre van szükség, mert a jelenleg érvényes szabályozás alacsonyabb beépítési százalékot és kisebb építménymagasságot enged meg a tervezettnél. A javasolt, módosított szabályozási tervet a fejlesztők a fejlesztési tervvel együtt elkészíttették. Ezek alapján a beépítés $65-80 \%$, a felszín alatti beépítés 65-100\% lehet, a megengedett építménymagasság $45 \mathrm{~m}$. A Csele utca rehabilitációja itt is szerepel. A telkeken a meglevő kereskedelem és szolgáltatások bővítése mellett irodákat, kulturális és sportlétesítményeket valamint lakófunkciót terveznek. A vegyes funkciók, a magas szintterületi mutató valamint a tervezett közparkok intenzív urbánus használatot eredményezhetnek a területen.

Ha a fejlesztés a terveknek megfelelően valósul meg, az összes beépített terület hozzávetôlegesen 30\%-a kereskedelmi funkciót kap. Ezt nem csupán a jelenlegi 


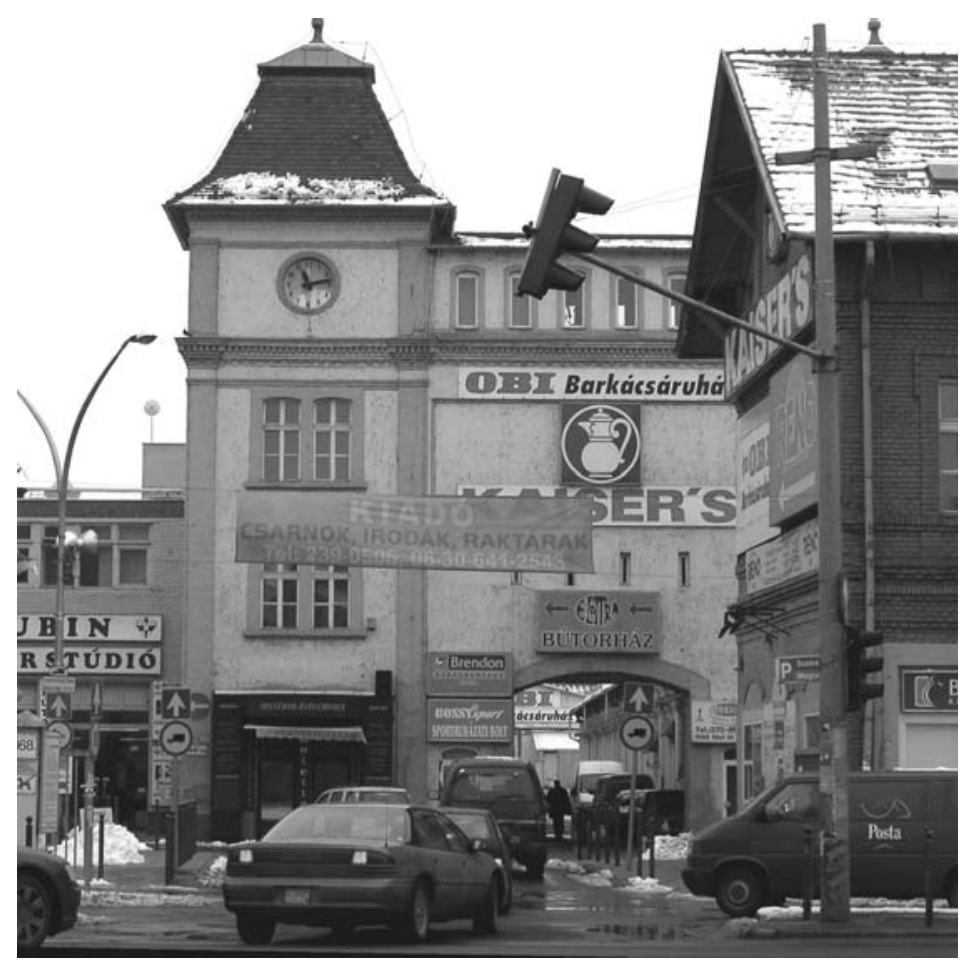

10. ábra. A városképi védettséget élvező kaputorony

igény indokolja, hanem a környéken tervezett beruházások is, amelyek túlnyomórészt lakó- és irodai funkciók kialakítását célozzák. Jelentős még az irodák és a lakások hányada, 20\% és 19\%. Ezek mellet a tervek szerint található lesz még a területen vendéglátás, szálló, kulturális, szabadidős és sportlétesítmények, valamint egyéb szolgáltatások. A funkciók térbeli elhelyezése a következő lesz:

- Irodák, szolgáltatások a Váci út mentén;

- Lakások a Rákos-patak és a Cserhalom u. mentén;

- Kereskedelem és egyéb funkciók a tömbök közepén;

- Zöldterületek a tömbök belsejében, a Rákos-patak felé a házak között (ez kapcsolódna a patak mentén tervezett zöld-rekreációs területhez) valamint egyes épületeken zöldtetők.

A beépítés keretes jellegü, de nem teljesen zártsorú, hasítékok átlátási, közlekedési lehetőséget nyújtanak. A terület déli részén lehetőség nyílik magasházak kialakítására, ezek szabadonálló toronyszerű építmények lehetnek. A tömbök belse- 
jében többszintes, változó szintszámú épületek zöldtetőkkel, burkolt felületekkel, parkokkal váltakozva. A két tömb között a Csele u. szintbeli keresztezése nélküli átjárást fognak biztosítani [17]. A tervezett funkciók és a progresszív építészeti megfogalmazás együttesen egy intenzíven használt, központ jellegü városi területet eredményezhet.

\section{A Váci út menti területek megújulásának meghatározói}

A Váci út mentén levő ingatlanok igen értékesek. Köszönhető ez a jó városszerkezeti elhelyezkedésnek, a Belváros és a Duna közelségének, a jó közlekedési lehetőségeknek (Váci út, metró), valamint a már meglevő szolgáltatásoknak. A közlekedés jelentőségét a megújulási folyamatokban az is mutatja, hogy a párhuzamos utcákban, a tömbök hátsó felén a barnamezők átalakulása lassabban, kisebb mértékben történt meg. A területek egyenletesebb megújulása a Váci útra merőleges, és az azzal párhuzamos mellékutcák közlekedési kapcsolatainak javításával elősegíthető lenne. A környező lakóterületek korábban a munkaerőt szolgáltatták az ipar számára, manapság már nem csupán munkaerőt, hanem a szolgáltatások iránti keresletet is biztosítják. Az ipartelepek privatizációja állami kezdeményezéssel, tervezetten ment végbe, de az azt követő korai ingatlanfejlesztési beruházások (bontások, új építések) spontán folyamatoknak tekinthetők. A példákból is látható, hogy a Váci út menti barnamezős területek magas értéküknél fogva ingatlanfejlesztési folyamatok során közpénzek bevonása nélkül is megújulnak. Ez a fővárosi és a kerületi önkormányzat koncepciójának is megfelel, ezért az újrahasznosítást mára részben irányítják, de támogatják is a területekre magalkotott szabályozási tervekkel. Az egyes ingatlanfejlesztési projekteket kiegészítő közberuházások (pl. útépítés) a fejlesztőktől begyưjtött hozzájárulásból finanszírozhatók.

A példákból leszürhető, hogy belvároshoz közelebb eső területek hamarabb, nagyobb arányban újultak meg, és még a Csavargyár esetén az ipari épületek újrahasznosítása rövidtávon is átmenetinek tekinthető, a távolabbi tömbökben egyes ipari épületek megőrzése, használata feltételezhetően hosszabb távú lesz.

\section{Az ipari épületek sorsa a Váci út mentén}

A váci út menti ipari területek ipartörténeti jelentősége számottevő. Egyes épületek emellett még kiemelkedő építészeti értékeket is hordoznak, ilyenek például az egykori Láng gépgyár múemlékké nyilvánított, Alpár Ignác által tervezett épületei (11. ábra). Az épített örökség védelme több szinten valósul meg: múemléki 


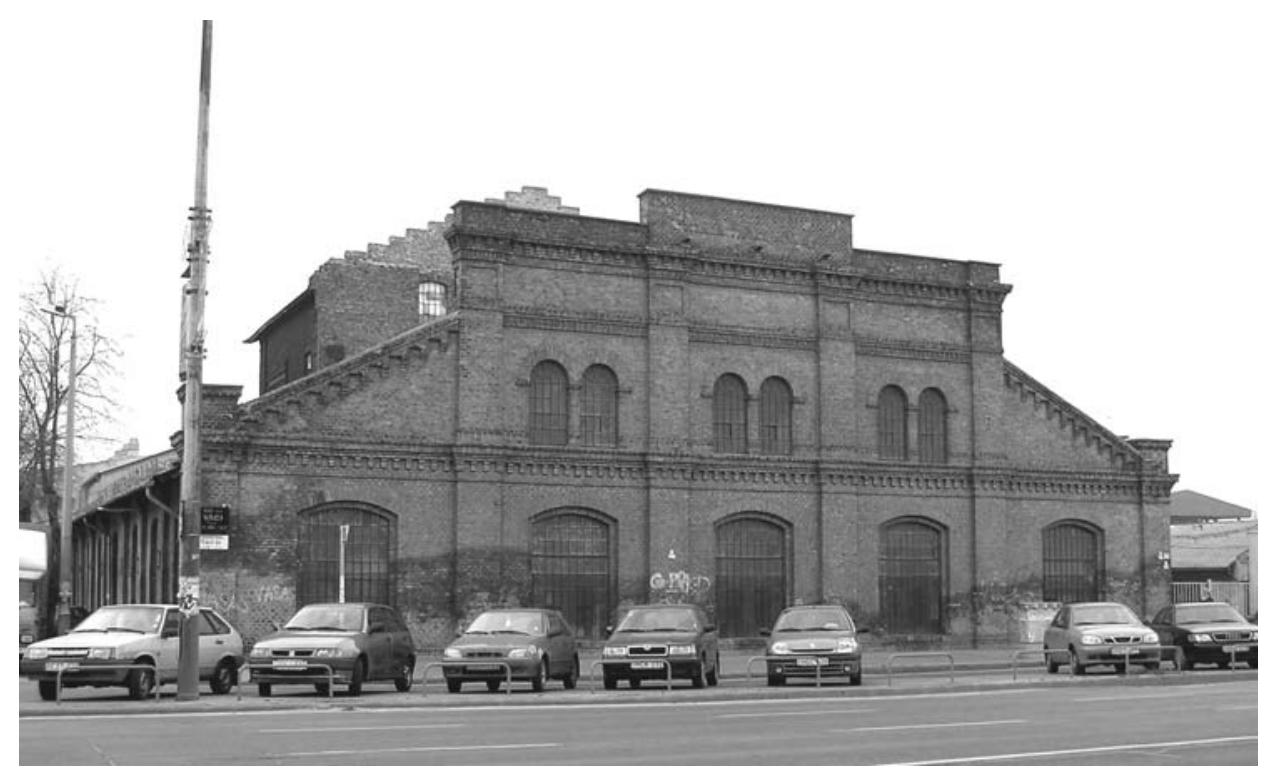

11. ábra. Az egykori Láng gépgyár csarnoka

vagy városi védettség. A vizsgált területeken még állnak egykori ipari épületek, azonban hosszú távú megtartásuk nem valószínű. Ezek az épületek nem állnak védettség alatt, bár összekapcsolódnak a terület gazdag ipartörténetével, történelmével. Egyedül a volt Csavargyár kapuzatának megőrzése biztosított városképi jelentősége miatt. A területek magas értéke, valamint a célzott kapacitás-növekedés azt eredményezi, hogy az elhagyott ipari épületeket végül elbontják, helyüket korszerü, a funkciónak jobban megfelelő új épületek veszik át.

\section{Gazdasági kérdések}

A területeken folyó fejlesztések magánberuházások, pontos gazdasági adatok nem ismertek. A befektetők üzleti célja a nyereség, a mihamarabbi megtérülés. A beruházás előtt komoly gazdaságossági vizsgálatokat készítenek, készítettnek, például a megvalósíthatósági tanulmány keretén belül. Ezek a vizsgálatok tartalmazzák a tervezett funkciókat és a hozzájuk rendelt kapacitást, területet. A belvárosi funkciók észak felé való kiterjedése valószínúsíti az irodai beruházások gyors megtérülését. Az új funkciókból, a területek megújulásából származó előnyök a hosszú és rövid távú társadalmi hasznon túl a vonzó környezetet teremtenek a további beruházásoknak. 


\section{ÖSSZEGZÉS}

A kutatás célja az ipar fejlődésének és a településszerkezet változásainak, a folyamatok egymásra hatásának vizsgálata, a megújulás folyamatát befolyásoló tényezők, azok hatásainak elemzése volt, az irodalomkutatás eredményeivel összehasonlítva.

A kiválasztott területek vizsgálatának eredményeképp megállapítható, hogy ez az egymásra hatás többrétü. A tanulmány bemutatja, hogy az egykori ipari területek ipari vagy egyéb funkcióval való megújulása nem modern jelenség, a folyamatra a XIX. század végétől lehet példákat találni. A barnamezős területek problémája azonban az ipari szerkezetváltás hatására vált ilyen hangsúlyossá.

A területek újrahasznositását gyakran éppen azok a tulajdonságok segítik elö, amik az ipar letelepedéséhez vezettek: jó közlekedési kapcsolatok, közelben levő lakó funkció. A megújulási folyamat összefügg a területek városszerkezeti helyével is. Megfigyelhető, hogy a belvároshoz fizikailag közelebb levő, vagy könynyebben elérhető területek hamarabb esnek át funkcióváltáson. A belvárostól, illetve a főbb útvonalaktól távolodva a hasznosítás intenzitása, a megújulás mértéke csökken.

A beruházások környezeti hatásait (közlekedés, épített és természetes környezet, szociológiai és gazdasági folyamatok) összefüggéseiben, nem egy-egy telekre, hanem nagyobb barnamezős területekre összefogottan szükséges vizsgálni. Ezek a munkák megalapozhatják a további fejlődést befolyásoló szabályozási terveket. A barnamezők teljes területre kiterjedő megújulásához az önkormányzatok részéröl tudatos irányitásra, esetleg kiegészitö beruházásokra (pl.feltáró utak építése, korszerüsitése) van szükség. İgy elősegíthető hogy, ne maradjanak meg zárványként elhagyatott, hasznosítatlan területek.

Az általam vizsgált esetekben kevéssé jellemző az ipari épületek újrahasznosítása. A kormányzat részéről sem merült fel igény a történeti ipari épületek megtartására, nem készült részletes elemzés, értékfeltárás. Mivel az ipari örökség és a történeti érték itt nem jelentkezik értéknövelö tényezöként, megörzése nem kap hangsúlyt, ellentétben a hamburgi eredményekkel [10]. Az épületek szennyezettségük, elavult állapotuk vagy a tervezett funkció befogadására kevéssé alkalmas szerkezeteik miatt általában lebontásra kerültek, vagy lebontásukat tervezik.

Az újrahasznosítás sikeressége csak évek távlatában vizsgálható, de a beruházásokkal azonnali eredmények is járnak: ilyen az építet környezet megújulása, a forgalom összetételének megváltozása, új zöldterületek kialakulása, a szennyező ipari tevékenységek hagyatékának felszámolása.

A célkitúzésben meghatározott szempontok, valamit az elvégzett vizsgálatok kijelölik a további kutatások irányát is. A barnamezős folyamatok további vizsgálata szükséges építészeti, gazdasági szempontból is. A városszerkezeti kutatások 
kibővítéseként célszerü lenne olyan területek vizsgálata, ahol a barnamezők megújulása összetettebb formában történik meg. A Váci úton a befektetők tervei közel azonosak az önkormányzat szándékaival, és így az építési szabályzatokon túl nincs szükség az önkormányzat további beavatkozására. A Metallochemia esetén ezzel ellentétben a beruházó maga az állam, így a megújulás megfelel a kormányzat terveinek. Ebben az esetben az állami beavatkozás tekinthető 100\%-osnak is. A két végletet megismerése mellett szükséges olyan példák elemzése is, ahol a magántőke és az önkormányzati szerepvállalás együttes hatásai figyelhetők meg.

\section{KÖSZÖNETNYILVÁNÍTÁS}

Ezúton szeretnék köszönetet mondani a sok segítségért és a hasznos információkért Arató Györgynek, Budapest XIII. kerület Főépítészének; Hajdú Árpádnénak és Sántha Dávidnak (Vegyépszer Rt.); Bata Gábornak (Repét Kft.).

\section{FORRÁSOK}

[1] Adametz Gy.: Angyalföld. Budapest XIII. kerület Önkormányzat, Budapest XIII. Kerületi Helytörténeti Klub, Budapest, 1998.

[2] Barta Gy. (témavezető): Gazdasági átalakulás Budapest rozsdaövezetében. MTA Regionális Kutatások Központja Közép- és Észak-Magyarországi Tudományos Intézet, Budapesti Osztály, Budapest, 2002.

[3] Budapest Főváros Városépítési Tervező Kft.: Budapest Településszerkezeti Terve (Egyeztetési dokumentáció). Budapest, 2003.

[4] Budapest, XIII. kerületi Önkormányzat, Főépítészi Iroda: Kerületi Szabályozási Tervek

[5] De Sousa, C. A.: Turning brownfields into green space in the City of Toronto. Landscape and Urban Planning 62(4), pp. 181-198, 2003.

[6] Ecorys Kft.: LOFT Program. Budapest, 2003.

[7] Fónagy Z., Korindesz M., Németh M., Zuglói L. Révész P., Nagy R.: Budapest gazdaságának 125 éve. Kamarapressz Kiadó és Szolgáltató Kht., Budapest, 1998.

[8] Gajdos E. et al.: Budapest, XIII. kerület: Angyalföld, Újlipótváros, Vizafogó. XIII. Kerületi Polgármesteri Hivatal, Budapest, 2000.

[9] Gazdasági és Közlekedési Minisztérium - KOPINT-DATORG Rt.: A 2010-ig szóló iparpolitika tudományos megalapozása Összefoglaló. Budapest, 2004.

[10] Haß, N. M. A. - Konerding, V. - Fernandéz, L. M. - Hinrichs, H. - Lau, S. - Lorenz, G. Mantlik, M. - Scheunemann, H.: Studie zu gewerblich genutzten und gesetzlich geschützten Denkmalen in Hamburg. Freie und Hansestadt Hamburg Kulturbehörde / Denkmalschutzamt, Jones Lang Wootton GmbH, Hamburg, 1996.

[11] Hrabál L.: A Vatea gyár története. A Rádiótechnikai Évkönyve, 2000 Zrínyi Kiadó, Budapest, 2000. pp. 4-13.

[12] Lepel A.: Ipari épületek, ipari területek változása Budapesten. Magyar Építöipar 54. évf. 11-12. pp. 302-311, 2003. 
[13] Metalloglobus Rt.: Szóbeli közlés. Budapest, 2005.

[14] Repét Kft.: Budapest, XXII. kerület Metallochemia telephely és környéke környezetvédelmi müszaki beavatkozás, Tenderterv, Budapest, 2004.

[15] Városkutatás Kft. (vezetésével múködő stratégiai csoport): Budapest Városfejlesztési Koncepció (összefoglaló). Budapest, 2003.

[16] Vegyépszer Rt.: Szóbeli közlés. Budapest, 2005.

[17] Z. Halmágyi J.: EEA tervezőiroda tervei, szóbeli közlés. Budapest, 2005.

[18] A Metallochemia 50 esztendeje 1908-1958. Budai Nyomda, Budapest, 1958.

\section{THE REUSE OF BROWNFIELDS IN BUDAPEST}

\section{Summary}

This paper deals with the redevelopment of the brownfield areas in Budapest. The paper presents the development of the Hungarian industry, and the expectable trends. It briefly summarises the changes affecting the city-structure of the Hungarian capital, and the industrial areas in Budapest from the beginning of the $19^{\text {th }}$ century to the present day. It also describes the evolution of brownfields and the initial processes of reuse.

I analyse the renewal of two brownfield areas in Budapest through examples: the former plot of Metallochemia in Nagytétény, and the neighbourhood of Váci út. I introduce the history of the industrial plots, the processes of redevelopment, the future of old industrial buildings on those plots, as well as financial issues. Among the aspects of the scrunity are the effects of urban plans, the role of the municipality, and the needs of the new function.

I examine the area in Nagytétény at first. The development on the plot of the former Metallochemia is a governmental initiative and it is far from downtown. The soil contamination determines the method of development. I demonstrate how the problem can be solved with highway M0-M6 leading across the plot.

Secondly, I examine three apartment blocks, demonstrating partly finished, partly planned processes. These sites have advantageous location in the city-structure, their redevelopments are private initiatives.

The results of these examinations are compared to each other and the international practices, so I could determine the factors influencing the process in the redevelopment of the brownfields in Budapest. These factors are, among others: the effects of the city-structure, and the role of the municipality.

Keywords: brownfield areas, redevelopment of brownfields, reuse of urban spaces, decontamination, industrial heritage 